\title{
Assessment of Teachers' Exposure to Noise in Selected Primary Schools
}

\author{
Danuta AUGUSTYŃSKA, Anna KACZMARSKA, \\ Witold MIKULSKI, Jan RADOSZ \\ Central Institute for Labour Protection \\ - National Research Institute \\ Czerniakowska 16, 00-701 Warszawa, Poland \\ e-mail: \{daaug, ankac, wimik, jarad\}@ciop.pl \\ (received June 15, 2010; accepted October 25, 2010)
}

\begin{abstract}
The assessment of teachers' exposure to noise in primary schools was carried out on the basis of: questionnaire studies (covering 187 teachers in 3 schools), noise measurements at the teachers' workplaces, measurements of the school rooms acoustic properties (reverberation time and speech transmission index STI in 72 classrooms), analysis of statistical data regarding hazards and occupational diseases in the education sector. The studies have shown that noise is the main factor of annoyance in the school environment. Over $50 \%$ of questioned teachers consider noise as annoying and near $40 \%$ as very annoying or unbearable. $A$-weighted equivalent continuous sound pressure levels measured in classrooms, teacher rooms and common rooms are in the range of $58-80 \mathrm{~dB}$ and they exceed $55 \mathrm{~dB}$ (criteria of noise annoyance). The most frequently reported subjective feelings and complaints (over 90\%) are: growth of psychical and emotional tension, irritation, difficulties in concentrating, hoarseness, cough. Noise in schools is also a harmful factor. High $A$-weighted equivalent continuous sound pressure levels ranging from 80 to $85 \mathrm{~dB}$, measured in corridors during pauses and in sports halls, can cause the risk of hearing damage among PE teachers and persons oversensitive to noise. The latter concerns both teachers and pupils. High background noise levels $(55-65 \mathrm{~dB})$ force teachers to raise their voice. It can lead to the development of an occupational disease - chronic voice disorders due to excessive vocal effort lasting for at least 15 years. In the education sector 785 new cases of this disease were reported only in 2008. Poor acoustics in classrooms (reverberation time ranging from 0.8 to $1.7 \mathrm{~s}$, STI $<0.6$ in $50 \%$ of classrooms) have an adverse influence on speech reception and make the teaching and learning processes difficult.
\end{abstract}

Keywords: primary school, noise, annoyance, harmfulness, questionnaire study, survey, acoustical measurements. 


\section{Introduction}

According to the report of the European Agency for Safety and Health at Work ("OSH in the...", 2009) a safe and healthy school, which ensures a secure environment for the pupils as well as the safety and health of the staff, is one of the main aims of membership countries of the European Union. This goal is realized among other things by including the problems of safety and health in the school environment into the programs of teaching on all levels, also to the university programs for teachers, engineers, architects, physicians, managers and so on. Those programs should be aimed at the ability to recognize possible dangers in the school environment, at the assessment of the healthy risks connected with those threats, at taking preventive measures and moulding safe behaviours.

The list of European activities for safe and healthy schools includes the realization of the task entitled "Assessment of the exposure to the school noise and the study of measures of prevention". This task was started in the Central Institute for Labour Protection on the proposal of the Ministry of National Education according to the public needs, within the scope of the National Programme "Improvement of the safety and working conditions" partly supported in 2008-2010 - within the scope of state services - by Ministry of Labour and Social Policy. The task of the study of school noise are also included in the project "Children Environment and Health Action Plan - CEHAP" prepared by the Ministry of Health, the Ministry of the Environment and World Health Organisation WHO (HANKE et al., 2009).

The studies of school noise has been doing so far by the National Institute of Hygiene during the years 1989-1996, the studies performed by the Institute of Occupational Medicine and Environmental Health in Sosnowiec aimed mainly at the voice disorders of teachers and the studies performed by different foreign centres aimed at the assessment of the climate and acoustic comfort of school rooms, of the speech comprehension and the conditions of speech communication (Astolfi, Pellerey, 2008; Augustyńska, Radosz, 2009a; 2009b; Bradley, Sato, 2008; Bronder, 2003; Koszarny, 1990; 1992; 2003; Lundquist et al., 2000; SATo, Bradley, 2008; Shield, Dockrell, 2004; VAlLET, Karabiber, 2002; Vilkman, 2004; Walinder et al., 2007) have indicated unfavourable acoustic conditions in Polish schools. High noise levels caused by the children activities especially in the corridors during pauses and in sports halls of primary schools (the $A$-weighted equivalent sound pressure level exceeds often 80-90 dB). The background noise levels in classrooms during lectures are within the limits of 53-77 dB; they depend on the type of classes. The mean noise level of the backgrounds, i.e. the noise arriving into the classrooms from all sources of noise, amounts to $40-50 \mathrm{~dB}$ and exceeds the limit 35-40 dB established in the national (PN-B-02151-02:1987) and foreign rules (VALLET, KARABIBER, 2002) for a correct speech reception. 
The noise level in primary schools is higher on average by about 5-6 dB than in secondary schools.

A comparison of the acoustic conditions in Polish schools with those in foreign schools indicated that the noise level in the corridors of Polish primary schools is in general by about $20 \mathrm{~dB}$ higher than that in corridors of foreign schools. The noise level is lowered in classrooms that have been acoustically adapted.

The unfavourable acoustic conditions in Polish schools are attributed to the fact that they are overcrowded and to their inappropriate architecture. Further reasons are insufficient technical protections against noise (including partitions isolating acoustically and acoustic adaptation of the rooms), inappropriate organising of the free time of pupils and their presence in the corridors during pauses instead on the sports ground. Because of the high background noise levels in the classrooms the teachers are forced to increase their voices in order to be understand. This leads to a larger vocal effort and voice disorders (BRONDER, 2003; Koszarny, 1992; Smith et al., 1998; Vilkman, 2004).

The school noise affects also the hearing organs of the pupils and teachers and disturb the speech reception and comprehension (KOSZARNY, 1992; VALLET, KARABIBER, 2002). This may cause some irritation of both the teachers and pupils, tiredness, lack of concentration and consequently a deterioration of the teaching and learning processes (LUNDQUIST et al., 2000; WALINDER et al., 2007).

This paper will show the current studies in the Central Institute for Labour Protection aimed at the assessment of the risk caused by noise for teachers in primary schools and the harmful consequences of such troublesome and damaging noise.

\section{Assumed research methodology}

The assessment of the exposure to noise has been based on:

- questionnaire study of teachers (187 persons from 3 primary schools),

- environmental examinations, i.e. measurements of noise at the teachers work positions,

- examinations of the acoustic properties of the school rooms,

- analysis of the data of Polish national statistics database concerning the hazards and occupational diseases registered in the Section Education, i.e. in institutions busy with education.

The study of teachers were made with questionnaires which contained questions about personal data, characteristic of working conditions (general assessment of the working conditions, sources of annoying factors and discomfort, noise sources, consequences and noticeable ailments arising from noise, subjective assessment of noise annoyance and the general assessment of the healthy state (subjective feelings and ailments and how often they appear). 
The description of the examined schools is given in Table 1, while that of the examined population (187 teachers) is show in Table 2 . The examinations have been performed anonymously and in accordance with all the rules concerning the protection of personal data. Data from the questionnaires have been put in a special data base that provided their processing and finding a dependence between the individual variables characteristic of the examined population. In the statistical analysis of the questionnaire results the tests of Mann-Whitney and Kruskal-Wallis were used for the calculation of the relevance of differences in the impressions connected with noise. For the analysis of the force of connection between 2 variables the Pearson's test was applied.

Table 1. Description of researched primary schools.

\begin{tabular}{|l|c|c|c|}
\hline School & School SP1 & School SP2 & School SP3 \\
\hline Year of construction & 1973 & 2003 & 1993 \\
\hline Building & Two-storey & Two-storey & One-storey \\
\hline School equipment & $\begin{array}{c}\text { Court, sports hall, } \\
\text { gym }\end{array}$ & $\begin{array}{c}\text { Court, sports hall } \\
\text { (sports centre) }\end{array}$ & $\begin{array}{c}\text { Court, sports hall, } \\
\text { gym }\end{array}$ \\
\hline $\begin{array}{l}\text { Situation } \\
\text { of school rooms }\end{array}$ & $\begin{array}{c}\text { One side } \\
\text { of corridor }\end{array}$ & $\begin{array}{c}\text { One side } \\
\text { of corridor }\end{array}$ & $\begin{array}{c}\text { Both sides } \\
\text { of corridor }\end{array}$ \\
\hline $\begin{array}{l}\text { School operation mode } \\
\text { Two shifts }\end{array}$ & $\begin{array}{c}\text { Two shifts } \\
(8.00-17.00)\end{array}$ & $\begin{array}{c}\text { Two shifts } \\
(8.00-16.00)\end{array}$ \\
\hline $\begin{array}{l}\text { Number of pupils: } \\
\text { total } \\
\text { single class }\end{array}$ & $\begin{array}{c}300 \\
\text { from } 17 \text { to } 26\end{array}$ & $\begin{array}{c}1273 \\
\text { from } 14 \text { to } 19\end{array}$ & $\begin{array}{c}660 \\
\text { from } 14 \text { to } 28\end{array}$ \\
\hline Number of classes & 17 & 30 & 30 \\
\hline Number of teachers & 43 & 145 & 83 \\
\hline
\end{tabular}

Survey research with respect to subjective feelings of the workers regarding working conditions and health are a common form, used for work condition review in member states of the European union (review conducted every 5 years by the European Foundation for the Improvement of Living and Working Conditions, based in Dublin). This research is an intermediate assessment method of the awareness of workers regarding the occupational risks and their effects on health and living. They are directly connected to the definition of health in the WHO constitution: "Health is a state of complete physical, mental and social well-being and not merely the absence of disease or infirmity".

Environmental noise measurements has been conducted in 3 primary schools, where surveys have been conducted regarding subjective feelings of teachers with respect to working conditions. Work posts and locations have been assessed: in classrooms, during various courses and lessons (integrated teaching, computer science, other subjects), in corridors (during breaks and lessons), at the sports hall 
Table 2. Description of the research population.

\begin{tabular}{|c|c|c|}
\hline Sex & $n$ & $\%$ \\
\hline male & 10 & 5.3 \\
\hline female & 177 & 94.7 \\
\hline total & 187 & 100 \\
\hline Age & $n$ & $\%$ \\
\hline under 25 & 4 & 2.1 \\
\hline $25-35$ & 74 & 39.6 \\
\hline $35-45$ & 56 & 29.9 \\
\hline $45-55$ & 46 & 24.6 \\
\hline over 55 & 7 & 3.7 \\
\hline total & 187 & 100 \\
\hline Subject $^{*}$ & $n$ & $\%$ \\
\hline integrated teaching & 56 & 29.9 \\
\hline computer science & 6 & 3.2 \\
\hline physical education & 14 & 7.5 \\
\hline practical/technical skills & 0 & 0 \\
\hline common room & 22 & 11.8 \\
\hline library & 4 & 2.1 \\
\hline other subjects & 90 & 48.1 \\
\hline total & 187 & - \\
\hline
\end{tabular}

\begin{tabular}{|l|r|c|}
\hline \multicolumn{1}{|c|}{ Teaching experience } & \multicolumn{1}{c|}{$n$} & $\%$ \\
\hline 1-5 years & 43 & 23 \\
\hline 6-10 years & 49 & 26.2 \\
\hline 11-15 years & 22 & 11.8 \\
\hline 16-20 years & 22 & 11.8 \\
\hline over 20 years & 51 & 27.3 \\
\hline total & 187 & 100 \\
\hline Weekly work load ${ }^{* *}$ & $n$ & $\%$ \\
\hline under 18 hours & 16 & 9 \\
\hline 18-27 hours & 152 & 85.4 \\
\hline over 27 hours & 10 & 5.6 \\
\hline total & 178 & 100 \\
\hline
\end{tabular}

* 5 persons reported two taught subjects

** Weekly work load from 2 to $43 \mathrm{~h}$, average $21 \mathrm{~h}$ (Weekly break duty time was 104 minutes on average).

during physical education, in the teachers' room (during breaks and lessons), in the library, the common room (daycare room) and the lunchroom. The basic measured values were: the $A$-weighted equivalent continuous sound pressure level while the teacher is at the work post or location, $L_{A e q}, T e$, the noise exposure level normalized to the nominal working week $\mathrm{L}_{E x, w}$, maximum $A$-weighted sound pressure level $L_{A \text { max }}$, the $C$-weighted peak sound pressure level $L_{\text {Cpeak }}$, the $A$-weighted equivalent continuous sound pressure level transmitted into the room from all sources $L_{A e q}$ i.e. the so-called background noise level. Research and noise assessment methods conforming to applicable regulations and standards have been used ("Ordinance of the Minister of Labour...", 2002; "Ordinance of the Minister of Infrastructure...", 2002; "Ordinance of the Minister of Environment...", 2007; PN-B-02151-02:1987; PN-B-02151-03:1999; PN-ISO 9612:2004; PN-N-01307:1994).

The assessment of acoustic properties of selected school rooms has been conducted in 3 selected schools. The reverberation time and the speech transmission index (STI) have also been measured (EN ISO 3382-2:2008; EN 60268-16:2003). 


\section{Results and discussion}

\subsection{Survey research results}

Questionnaire results, i.e. the subjective evaluation of noise risks and the assessment of teachers' noise-related ailments have been presented in Figs. 1 to 5 .

When assessing the work environment factors as the main sources of ailments and discomfort, the teachers have indicated noise (88.2\%), small rooms (32.1\%), bad ventilation (27.3\%), lighting (13.9\%) (Fig. 1). Corridor noise during breaks (83.5\%), physical education classes in corridors (34.5\%), school bell $(31.4 \%)$ and students' conversations during lessons $(30 \%)$ have been named as the most annoying noise sources in schools (Fig. 2).

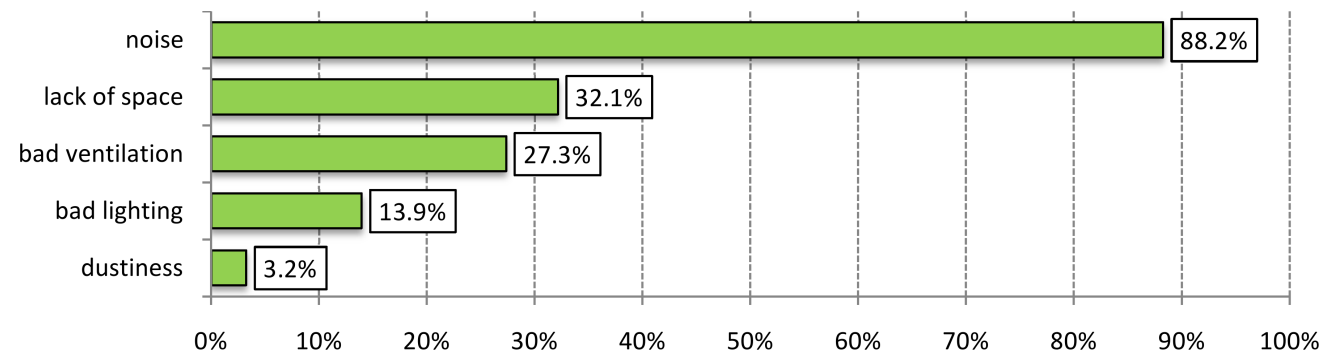

Fig. 1. Annoyance and discomfort sources, as indicated by surveyed teachers $(n=187)$.

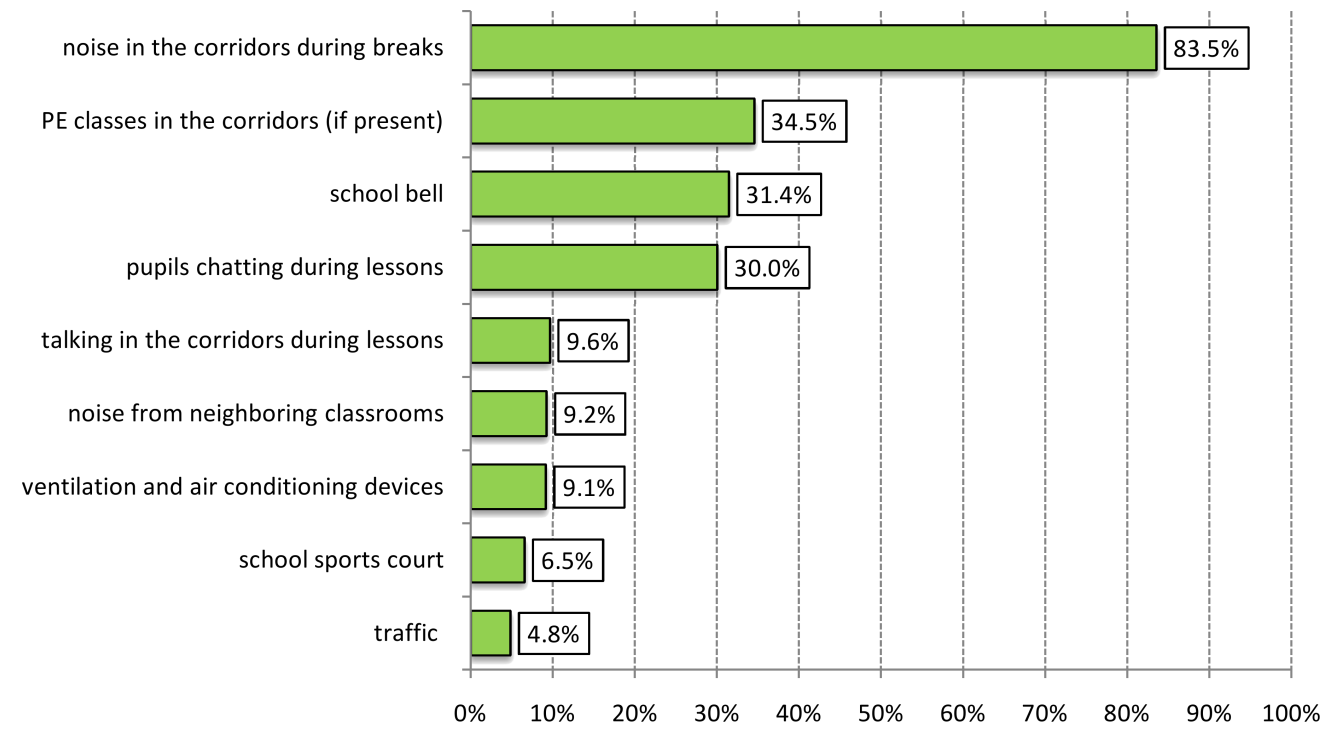

Fig. 2. Most annoying noise sources.

Over $70 \%$ participants considered noise in schools as loud or very loud, irritating, distressing, distracting and making it hard to concentrate (Fig. 3). A sig- 


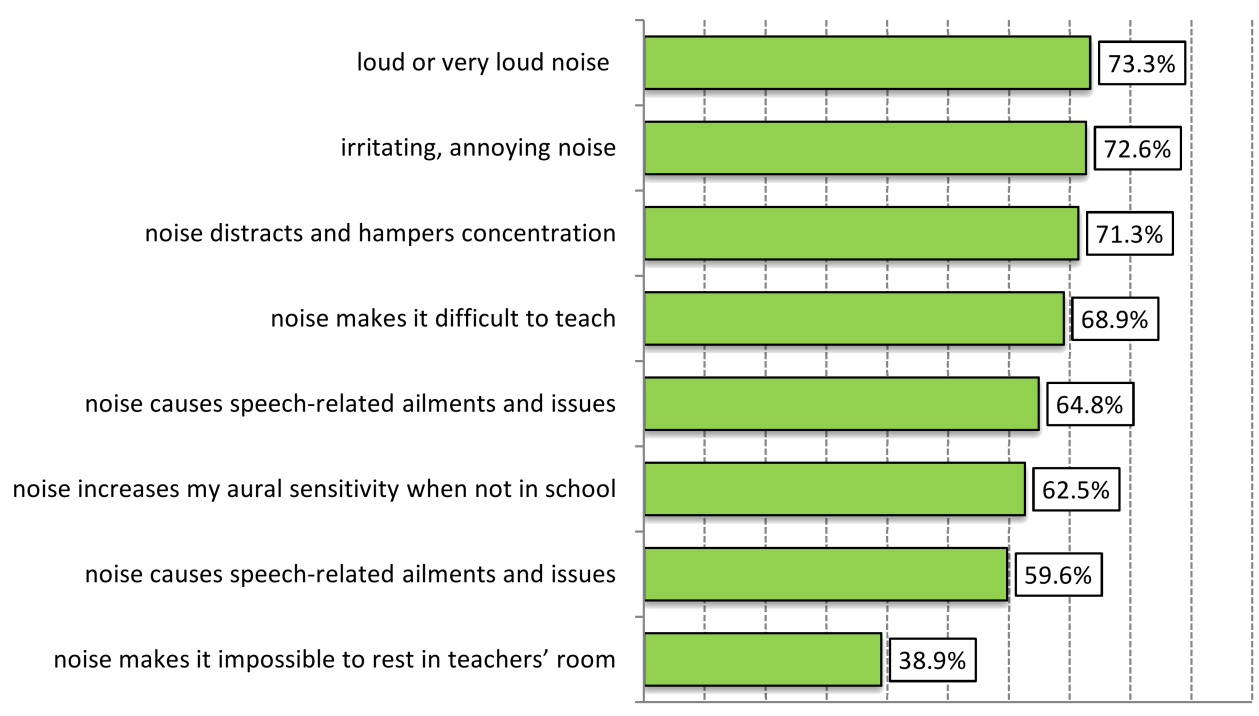

$\begin{array}{llllllllllll}0 & 0 & 10 \% & 20 \% & 30 \% & 40 \% & 50 \% & 60 \% & 70 \% & 80 \% & 90 \% & 100 \%\end{array}$

Fig. 3. Noise-related feelings in school.

nificant percentage of teachers indicated that school noise makes teaching difficult $(68.9 \%)$, interferes with conversations $(64.8 \%)$, increases noise sensitivity in out-of-school situations (62.\%). 106 participants (59.6\%) claimed that noise is a reason of ailments and voice problems. When assessing the ailments and feelings which could be caused by school noise, $75 \%$ participants claimed that noise causes fatigue, $61.3 \%$ indicated discomfort, $50 \%$ headaches and $48.8 \%$ - distraction (Fig. 4).

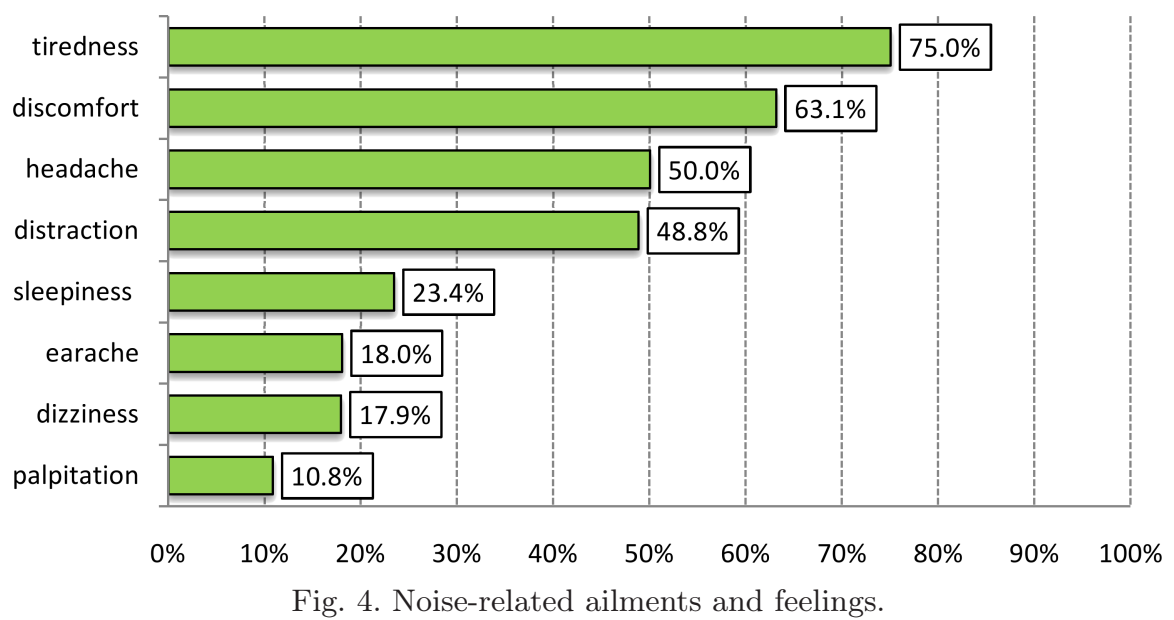

On a noise annoyance scale from 1 to $10,42.4 \%$ teachers claimed that noise is very annoying or hardly bearable (annoyance rating 8 and above) (Fig. 5a). 
Only $7 \%$ of teachers evaluated noise as non-annoying or hardly annoying (annoyance rating 3 and below). Comparison of annoyance features broken down by schools shows that the highest annoyance ranks (6 and 8) have been submitted by teachers from the SP1 school (Fig. 5b).

a)

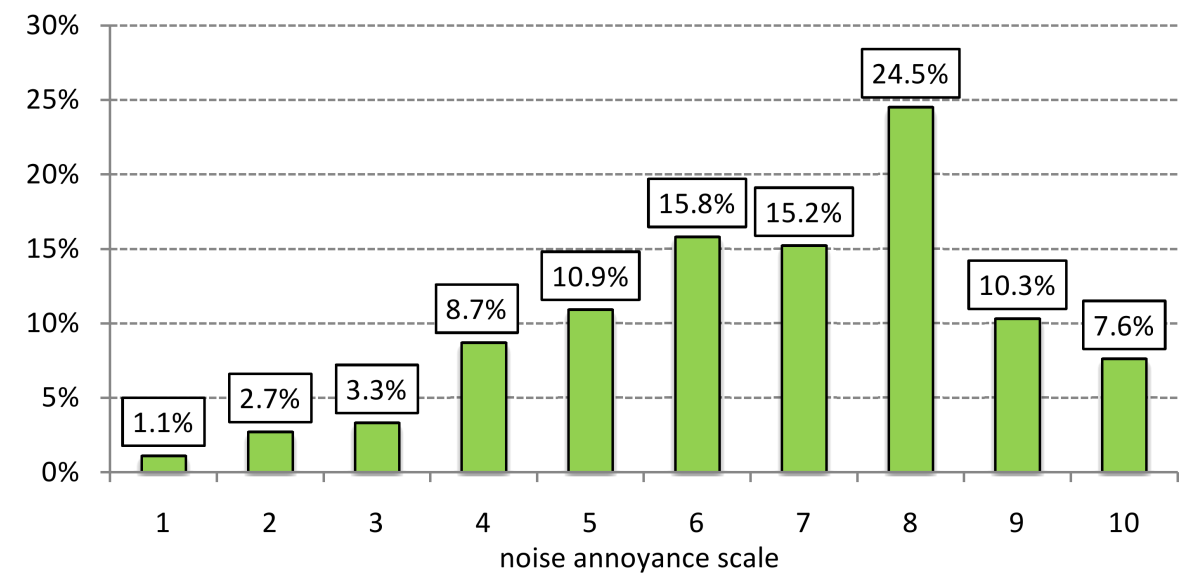

b)

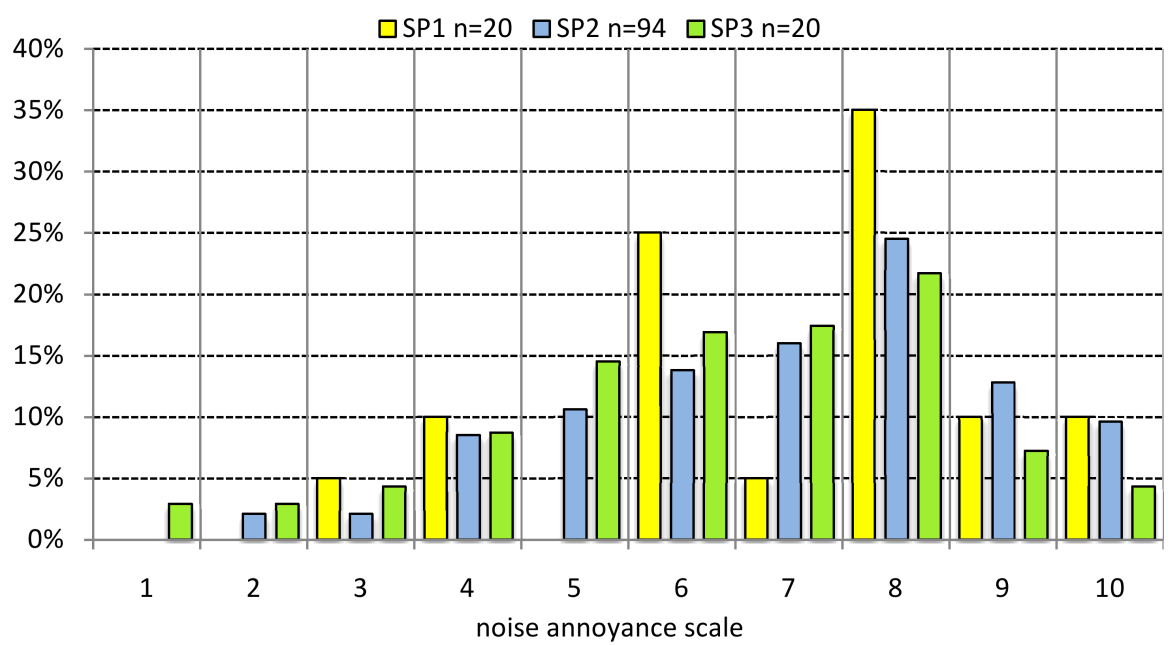

Fig. 5. Noise annoyance scale from 1 to 10: a) for all schools total, b) broken down by individual schools.

To assess the frequency of subjective feelings and ailments, the surveyed population has been divided into 5 groups (Table 3). In groups 1, 2 and 3 (ailments occurring everyday, 2-3 times a week and once or several times a month), the largest part of teachers indicated the following ailments: increasing fatigue during the day $-89.1 \%$, feeling of nervousness or irritation $-82 \%$, increase of psychical and emotional tension $-80.8 \%$, waking up with the feeling of fatigue and sleepi- 
Table 3. Frequency of occurrence or appearance of subjective ailments.

\begin{tabular}{|c|c|c|c|c|c|c|}
\hline \multirow[b]{2}{*}{ Ailment } & \multicolumn{5}{|c|}{ Frequency of occurrence or appearance* } & \multirow[b]{2}{*}{ Total } \\
\hline & $\begin{array}{c}\text { Group } \\
0\end{array}$ & $\begin{array}{c}\text { Group } \\
1\end{array}$ & $\begin{array}{c}\text { Group } \\
2\end{array}$ & \begin{tabular}{c|} 
Group \\
3
\end{tabular} & $\begin{array}{c}\text { Group } \\
4\end{array}$ & \\
\hline Heart rate increased & $\begin{array}{c}43 \\
26.1 \% \\
\end{array}$ & $\begin{array}{c}11 \\
6.7 \% \\
\end{array}$ & $\begin{array}{c}34 \\
20.6 \% \\
\end{array}$ & $\begin{array}{c}36 \\
21.8 \% \\
\end{array}$ & $\begin{array}{c}41 \\
24.8 \% \\
\end{array}$ & $\begin{array}{c}n=165 \\
100 \%\end{array}$ \\
\hline $\begin{array}{l}\text { Increase of psychological } \\
\text { and emotional tension }\end{array}$ & $\begin{array}{c}8 \\
4.8 \% \\
\end{array}$ & $\begin{array}{c}36 \\
21.6 \% \\
\end{array}$ & $\begin{array}{c}42 \\
25.1 \% \\
\end{array}$ & \begin{tabular}{c|}
57 \\
$34.1 \%$ \\
\end{tabular} & $\begin{array}{c}24 \\
14.4 \% \\
\end{array}$ & $\begin{array}{c}n=167 \\
100 \%\end{array}$ \\
\hline Vertigo & $\begin{array}{c}69 \\
40.4 \% \\
\end{array}$ & $\begin{array}{c}3 \\
1.8 \% \\
\end{array}$ & \begin{tabular}{c|}
22 \\
$12.9 \%$ \\
\end{tabular} & $\begin{array}{c}36 \\
21.1 \% \\
\end{array}$ & $\begin{array}{c}41 \\
24 \% \\
\end{array}$ & $\begin{array}{c}n=171 \\
100 \%\end{array}$ \\
\hline Palpitations & $\begin{array}{c}61 \\
36.1 \% \\
\end{array}$ & $\begin{array}{c}7 \\
4.1 \% \\
\end{array}$ & $\begin{array}{c}26 \\
15.4 \% \\
\end{array}$ & $\begin{array}{c}33 \\
19.5 \% \\
\end{array}$ & $\begin{array}{c}42 \\
24.9 \% \\
\end{array}$ & $\begin{array}{c}n=169 \\
100 \%\end{array}$ \\
\hline Excessive perspiration & \begin{tabular}{c|}
59 \\
$35.3 \%$ \\
\end{tabular} & $\begin{array}{c}11 \\
15 \% \\
\end{array}$ & $\begin{array}{c}25 \\
15 \% \\
\end{array}$ & $\begin{array}{c}38 \\
22.8 \% \\
\end{array}$ & $\begin{array}{c}34 \\
20.4 \% \\
\end{array}$ & $\begin{array}{c}n=167 \\
100 \%\end{array}$ \\
\hline Sultriness & $\begin{array}{c}84 \\
50.3 \% \\
\end{array}$ & $\begin{array}{l}6 \\
3.6 \% \\
\end{array}$ & $\begin{array}{r}15 \\
9 \% \\
\end{array}$ & $\begin{array}{c}31 \\
18.6 \% \\
\end{array}$ & $\begin{array}{c}31 \\
18.6 \% \\
\end{array}$ & $\begin{array}{c}n=167 \\
100 \%\end{array}$ \\
\hline $\begin{array}{l}\text { Increasing fatigue } \\
\text { during the day }\end{array}$ & $\begin{array}{c}3 \\
1.7 \% \\
\end{array}$ & $\begin{array}{c}63 \\
36.2 \% \\
\end{array}$ & \begin{tabular}{c|}
49 \\
$28.2 \%$ \\
\end{tabular} & \begin{tabular}{c|}
43 \\
$24.7 \%$ \\
\end{tabular} & $\begin{array}{c}16 \\
9.2 \% \\
\end{array}$ & $\begin{array}{c}n=174 \\
100 \%\end{array}$ \\
\hline $\begin{array}{l}\text { Waking up with feeling } \\
\text { of fatigue or sleepiness }\end{array}$ & $\begin{array}{c}10 \\
5.7 \% \\
\end{array}$ & $\begin{array}{c}21 \\
12.1 \% \\
\end{array}$ & $\begin{array}{c}60 \\
34.5 \% \\
\end{array}$ & $\begin{array}{c}53 \\
30.5 \% \\
\end{array}$ & $\begin{array}{c}30 \\
17.2 \% \\
\end{array}$ & $\begin{array}{c}n=174 \\
100 \%\end{array}$ \\
\hline $\begin{array}{l}\text { Feeling of apathy } \\
\text { and indifference }\end{array}$ & $\begin{array}{c}27 \\
16.4 \% \\
\end{array}$ & $\begin{array}{c}4 \\
2.4 \% \\
\end{array}$ & $\begin{array}{c}28 \\
17 \% \\
\end{array}$ & \begin{tabular}{c|}
54 \\
$32.7 \%$ \\
\end{tabular} & $\begin{array}{c}52 \\
31.5 \% \\
\end{array}$ & $\begin{array}{c}n=165 \\
100 \%\end{array}$ \\
\hline $\begin{array}{l}\text { Feeling of nervousness } \\
\text { and irritation }\end{array}$ & $\begin{array}{c}5 \\
2.9 \% \\
\end{array}$ & $\begin{array}{c}17 \\
9.9 \%\end{array}$ & $\begin{array}{c}51 \\
29.7 \% \\
\end{array}$ & $\begin{array}{c}73 \\
42.4 \% \\
\end{array}$ & $\begin{array}{c}26 \\
15.1 \% \\
\end{array}$ & $\begin{array}{c}n=172 \\
100 \%\end{array}$ \\
\hline Difficulty falling asleep & $\begin{array}{c}50 \\
29.9 \% \\
\end{array}$ & $\begin{array}{l}10 \\
6 \% \\
\end{array}$ & $\begin{array}{c}19 \\
11.4 \% \\
\end{array}$ & \begin{tabular}{c|}
47 \\
$28.1 \%$ \\
\end{tabular} & \begin{tabular}{c|}
41 \\
$24.6 \%$ \\
\end{tabular} & $\begin{array}{c}n=167 \\
100 \%\end{array}$ \\
\hline $\begin{array}{l}\text { Agitated sleep, waking up } \\
\text { in the night }\end{array}$ & $\begin{array}{c}39 \\
23.5 \% \\
\end{array}$ & $\begin{array}{c}13 \\
7.8 \% \\
\end{array}$ & $\begin{array}{c}18 \\
10.8 \% \\
\end{array}$ & $\begin{array}{c}50 \\
30.1 \% \\
\end{array}$ & $\begin{array}{c}46 \\
27.7 \% \\
\end{array}$ & $\begin{array}{c}n=166 \\
100 \%\end{array}$ \\
\hline $\begin{array}{l}\text { Difficulty concentrating } \\
\text { on performed activity }\end{array}$ & $\begin{array}{c}16 \\
9.3 \% \\
\end{array}$ & $\begin{array}{c}8 \\
4.8 \% \\
\end{array}$ & $\begin{array}{c}28 \\
16.3 \% \\
\end{array}$ & $\begin{array}{c}76 \\
44.2 \% \\
\end{array}$ & $\begin{array}{c}42 \\
24.4 \% \\
\end{array}$ & $\begin{array}{c}n=170 \\
100 \%\end{array}$ \\
\hline Frequent headaches & $\begin{array}{c}25 \\
14.6 \% \\
\end{array}$ & $\begin{array}{c}11 \\
6.4 \% \\
\end{array}$ & $\begin{array}{c}29 \\
17 \% \\
\end{array}$ & $\begin{array}{c}59 \\
34.5 \% \\
\end{array}$ & $\begin{array}{c}47 \\
27.5 \% \\
\end{array}$ & $\begin{array}{c}n=171 \\
100 \%\end{array}$ \\
\hline $\begin{array}{l}\text { Chronic inflammation } \\
\text { of larynx }\end{array}$ & $\begin{array}{c}65 \\
38.9 \% \\
\end{array}$ & $\begin{array}{c}0 \\
0 \% \\
\end{array}$ & $\begin{array}{c}8 \\
4.8 \% \\
\end{array}$ & $\begin{array}{c}17 \\
10.2 \% \\
\end{array}$ & $\begin{array}{c}77 \\
46.1 \% \\
\end{array}$ & $\begin{array}{c}n=167 \\
100 \%\end{array}$ \\
\hline $\begin{array}{l}\text { Feeling of dryness } \\
\text { and sore throat }\end{array}$ & $\begin{array}{c}16 \\
9.3 \% \\
\end{array}$ & $\begin{array}{c}17 \\
9.9 \% \\
\end{array}$ & $\begin{array}{c}31 \\
18 \% \\
\end{array}$ & $\begin{array}{c}58 \\
33.7 \% \\
\end{array}$ & $\begin{array}{c}50 \\
29.1 \% \\
\end{array}$ & $\begin{array}{c}n=172 \\
100 \%\end{array}$ \\
\hline Hoarseness, cough & $\begin{array}{c}15 \\
8.7 \% \\
\end{array}$ & $\begin{array}{c}7 \\
4 \% \\
\end{array}$ & $\begin{array}{c}17 \\
9.8 \% \\
\end{array}$ & $\begin{array}{c}53 \\
30.6 \%\end{array}$ & $\begin{array}{c}81 \\
46.8 \% \\
\end{array}$ & $\begin{array}{c}n=173 \\
100 \%\end{array}$ \\
\hline $\begin{array}{l}\text { Aural discomfort (ringing, buzzing, } \\
\text { whistling, wind noise, pulsation, etc.) }\end{array}$ & \begin{tabular}{c|}
64 \\
$38.1 \%$ \\
\end{tabular} & $\begin{array}{l}6 \\
3.6 \% \\
\end{array}$ & $\begin{array}{c}18 \\
10.7 \% \\
\end{array}$ & $\begin{array}{c}29 \\
17.3 \% \\
\end{array}$ & $\begin{array}{c}51 \\
30.4 \% \\
\end{array}$ & $\begin{array}{c}n=168 \\
100 \%\end{array}$ \\
\hline
\end{tabular}

* Division into groups:

Group 0 - persons not suffering from ailment;

Group 1 - persons suffering from given ailment daily;

Group 2 - persons suffering from given ailment 2-3 times a week;

Group 3 - persons suffering from given ailment once or several times a month;

Group 4 - persons suffering from given ailment several times a year. 
ness $-77.1 \%$, difficulty in concentrating on the performed activity $-65.3 \%$. In group 4, i.e. the group of persons suffering from ailments rarely - several times a year, the teachers complained mostly about hoarseness, cough $-46.8 \%$, feeling of throat dryness or soreness $-29.1 \%$, chronic larynx inflammation $-46.1 \%$, aural buzzing $-30.4 \%$.

Statistical analysis of relations between the subjective evaluation of noise risks, its conditions and felt ailments has shown statistically significant differences $(p<0.05)$ with regard to noise-related feelings and job tenure, inter alia in the "noise distracts attention and hampers concentration" category (Fig. 6). It turned out that the group of teachers most exposed to distraction of attention is the group with an average job tenure (11 to 20 years). The least exposed group are the youngest workers (job tenure 1 to 10 years).

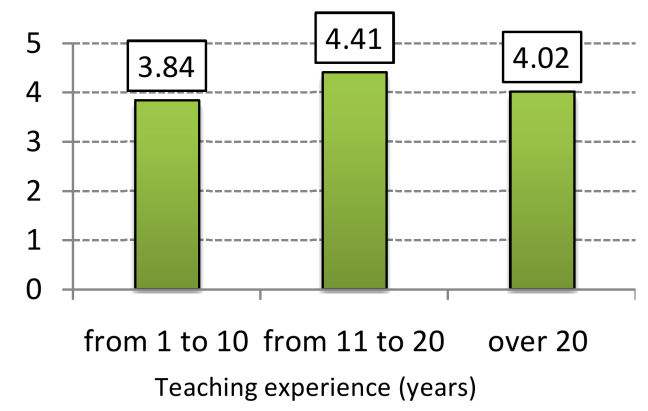

Fig. 6. Results of evaluation of noise sensation (noise distract attention and hampers concentration) in relation to teaching experience (scale: $0-5$ ). Statistical significance - Kruskal Wallis test $-p<0.01$.

It also turned out that there is a connection between the weekly work load and the evaluation of noise annoyance (Fig. 7). Teachers with a higher work load found the noise less annoying. Such ratings can be explained by the habitation effect, i.e. the influence of long noise exposure on reduction of perceived annoyance.

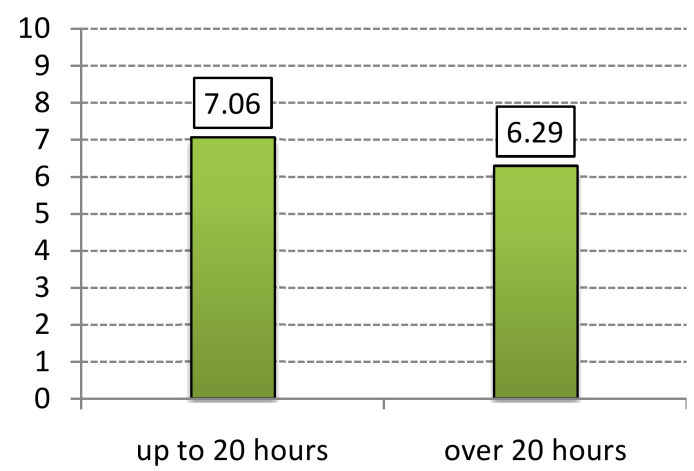

Fig. 7. Noise arduousness evaluation results (scale 1-10) of persons with higher (over 20 hours) and lower (up to 20 hours) weekly didactic work load. Statistical significance - Mann-Whitney test $-p<0.01$. 
Correlation between teachers' job tenure, subjective noise evaluation and the ailments and health issues (Table 4) show statistically significant correlation between:

- job tenure and the frequency of increasing fatigue during the day and concentration difficulties,

Table 4. Correlation between job tenure and perceived noise-related annoyance and healthrelated issues.

\begin{tabular}{|c|c|c|c|}
\hline & & $\begin{array}{c}\text { Job } \\
\text { tenure }\end{array}$ & $\begin{array}{l}\text { Subjective } \\
\text { annoyance } \\
\text { evaluation }\end{array}$ \\
\hline \multirow{2}{*}{ Job tenure } & Pearson correlation & 1 & -.030 \\
\hline & Relevance (bilateral) & . & .686 \\
\hline \multirow{2}{*}{ Subjective annoyance evaluation } & Pearson correlation & -.030 & 1 \\
\hline & Relevance (bilateral) & .686 & . \\
\hline \multirow{2}{*}{ Increase of psychological and emotional tension } & Pearson correlation & .131 & $.314\left(^{* *}\right)$ \\
\hline & Relevance (bilateral) & .084 & .000 \\
\hline \multirow{2}{*}{ Increasing fatigue during the day } & Pearson correlation & $.172\left(^{*}\right)$ & $.312\left(^{* *}\right)$ \\
\hline & Relevance (bilateral) & .024 & .000 \\
\hline \multirow{2}{*}{ Waking up with feeling of fatigue or sleepiness } & Pearson correlation & .026 & $.401\left({ }^{* *}\right)$ \\
\hline & Relevance (bilateral) & .730 & .000 \\
\hline \multirow{2}{*}{ Feeling of apathy and indifference } & Pearson correlation & .035 & $.221\left(^{* *}\right)$ \\
\hline & Relevance (bilateral) & .654 & .005 \\
\hline \multirow{2}{*}{ Feeling of nervousness and irritation } & Pearson correlation & .075 & $.357\left({ }^{* *}\right)$ \\
\hline & Relevance (bilateral) & .328 & .000 \\
\hline \multirow{2}{*}{ Difficulty concentrating on performed activity } & Pearson correlation & $.158\left(^{*}\right)$ & $.306\left(^{* *}\right)$ \\
\hline & Relevance (bilateral) & .039 & .000 \\
\hline \multirow{2}{*}{ Frequent headaches } & Pearson correlation & .024 & $.315\left(^{* *}\right)$ \\
\hline & Relevance (bilateral) & .758 & .000 \\
\hline \multirow{2}{*}{ Chronic inflammation of larynx } & Pearson correlation & .018 & $.303\left(^{* *}\right)$ \\
\hline & Relevance (bilateral) & .816 & .000 \\
\hline \multirow{2}{*}{ Feeling of dryness and sore throat } & Pearson correlation & .069 & .072 \\
\hline & Relevance (bilateral) & .363 & .349 \\
\hline \multirow{2}{*}{ Hoarseness. cough } & Pearson correlation & .107 & $.237\left(^{* *}\right)$ \\
\hline & Relevance (bilateral) & .162 & .002 \\
\hline \multirow{2}{*}{ Aural discomfort } & Pearson correlation & .111 & $.184\left(^{*}\right)$ \\
\hline & Relevance (bilateral) & .150 & .017 \\
\hline
\end{tabular}

* Correlation is significant on the 0.05 level (bilaterally).

** Correlation is significant on the 0.01 level (bilaterally). 
- subjective evaluation of noise annoyance and the frequency of: increase of psychological and emotional tension, increasing fatigue during the day, waking up with the feeling of fatigue and sleepiness, feelings of apathy and indifference, feeling of anger and irritation, concentration difficulties, frequent headaches, chronic larynx inflammations, hoarseness, cough and aural buzzing.

\subsection{Results of the environmental research}

Results of the environmental research, i.e. objective noise risk assessment, conducted on teachers' work posts in three primary schools, where survey research regarding subjective evaluation of noise risk had been performed earlier, have been presented in Figs. 8 to 11.

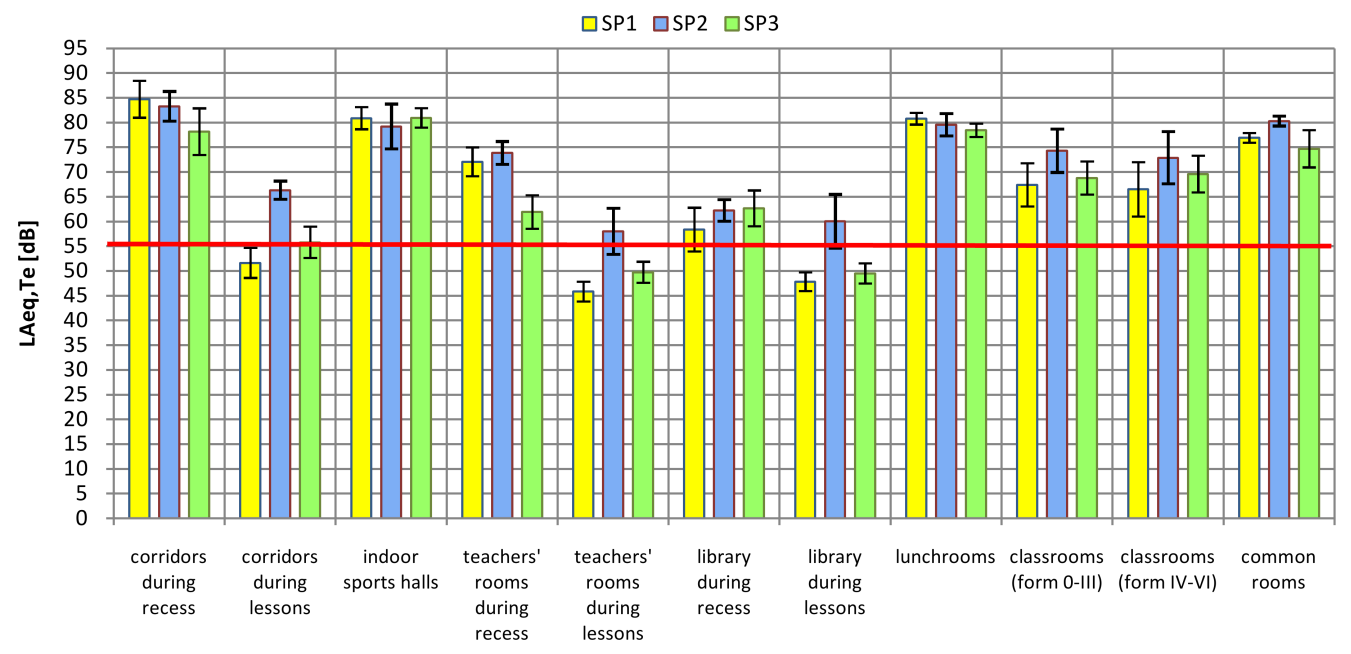

Fig. 8. A-weighted sound equivalent pressure levels, $L_{A e q, T e}$, on teachers' work posts in researched primary schools (noise annoyance criterion $-L_{A e q, T e}=55 \mathrm{~dB}$ ).

Measurements have shown that corridors are the loudest spaces in two schools examined (SP2 and SP1). $A$-weighted equivalent continuous sound pressure levels are $83.3 \mathrm{~dB}$ and $84.7 \mathrm{~dB}$, respectively (Fig. 8). Maximum $A$-weighted sound pressure levels reach the values of $95.4 \mathrm{~dB}$ and $99.4 \mathrm{~dB}$ (Fig. 9), and the $C$-weighted peak noise levels $-112-113.5$ dB (Fig. 10). In school SP3, the $A$-weighted equivalent continuous sound pressure level in corridors during breaks is $78.2 \mathrm{~dB}$, the maximum $A$-weighted sound pressure level $-86.4 \mathrm{~dB}$, and the peak level - $108.9 \mathrm{~dB}$. Lower noise levels in this school's corridors are caused by a nonstandard architectural layout - angled corridors.

During lessons, the noise in all schools' corridors is significantly lower. The $A$-weighted equivalent continuous sound pressure level ranges from 51.6 to $66.3 \mathrm{~dB}$, 


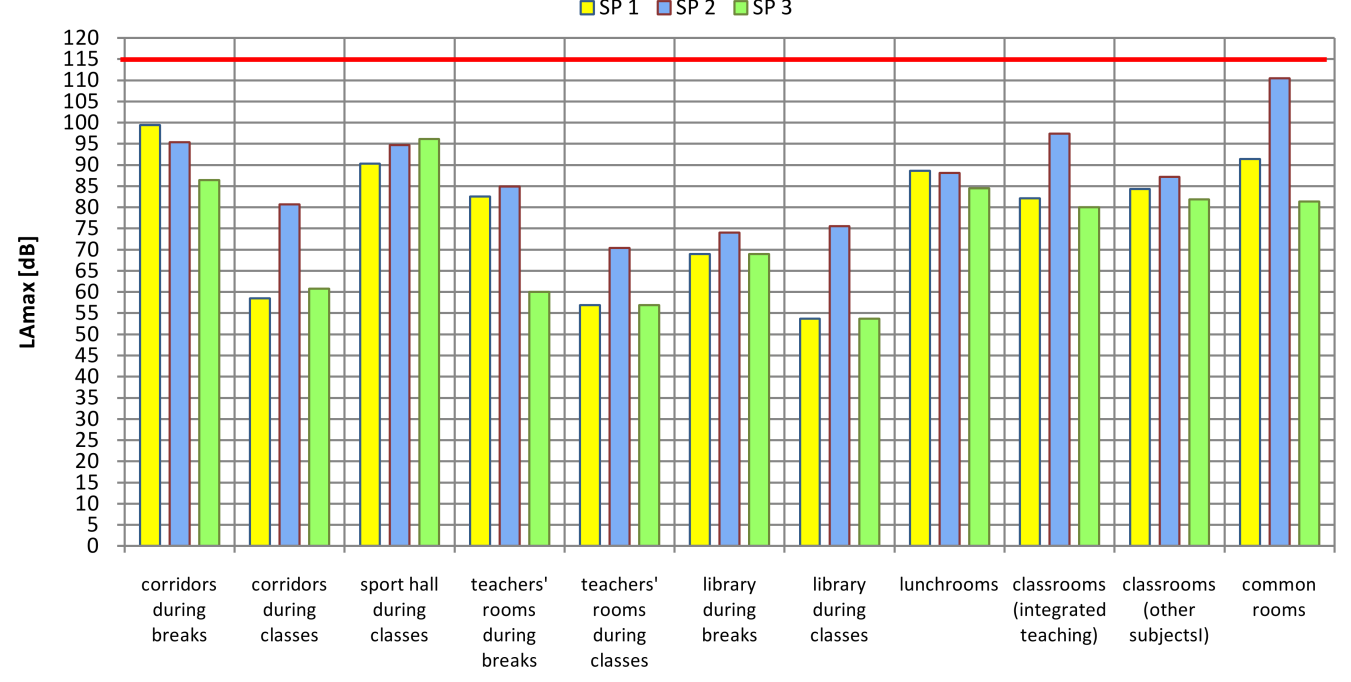

Fig. 9. $A$-weighted maximum sound pressure levels $L_{A \text { max }}$ when the teacher is present at the work post in researched primary schools (MAI value $-L_{A \max }=115 \mathrm{~dB}$ ).

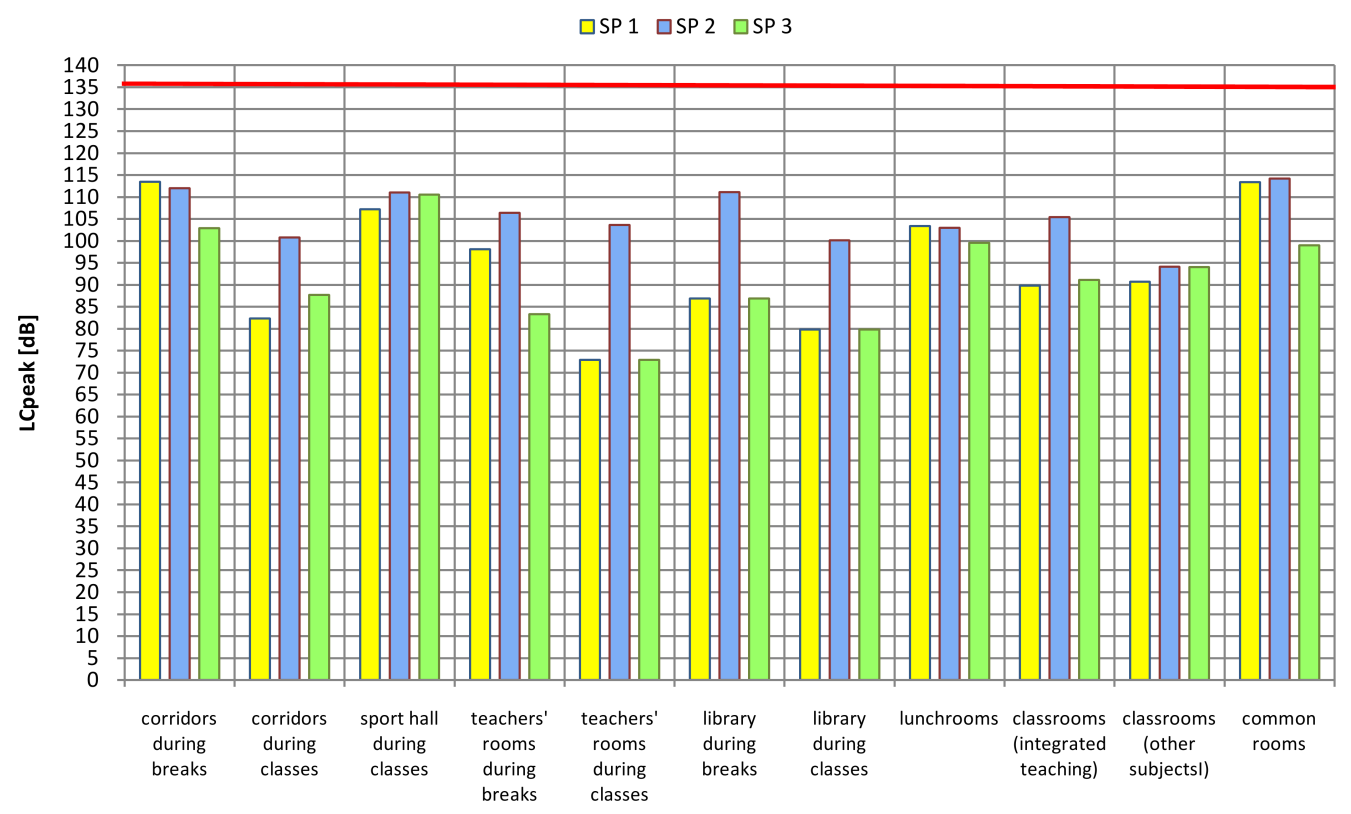

Fig. 10. $C$-weighted peak sound pressure levels, $L_{C \text { peak }}$, in researched primary schools $\left(\right.$ MAI value $\left.-L_{C \text { peak }}=135 \mathrm{~dB}\right)$.

maximum $A$-weighted sound pressure level $-58.5-80.7 \mathrm{~dB}$, and the $C$-weighted peak noise level - 82.3-100.8 dB.

Sports halls during classes (schools SP1 and SP3) and corridors during physical education lessons (school SP2) are also considered loud spaces. $A$-weighted 
a)
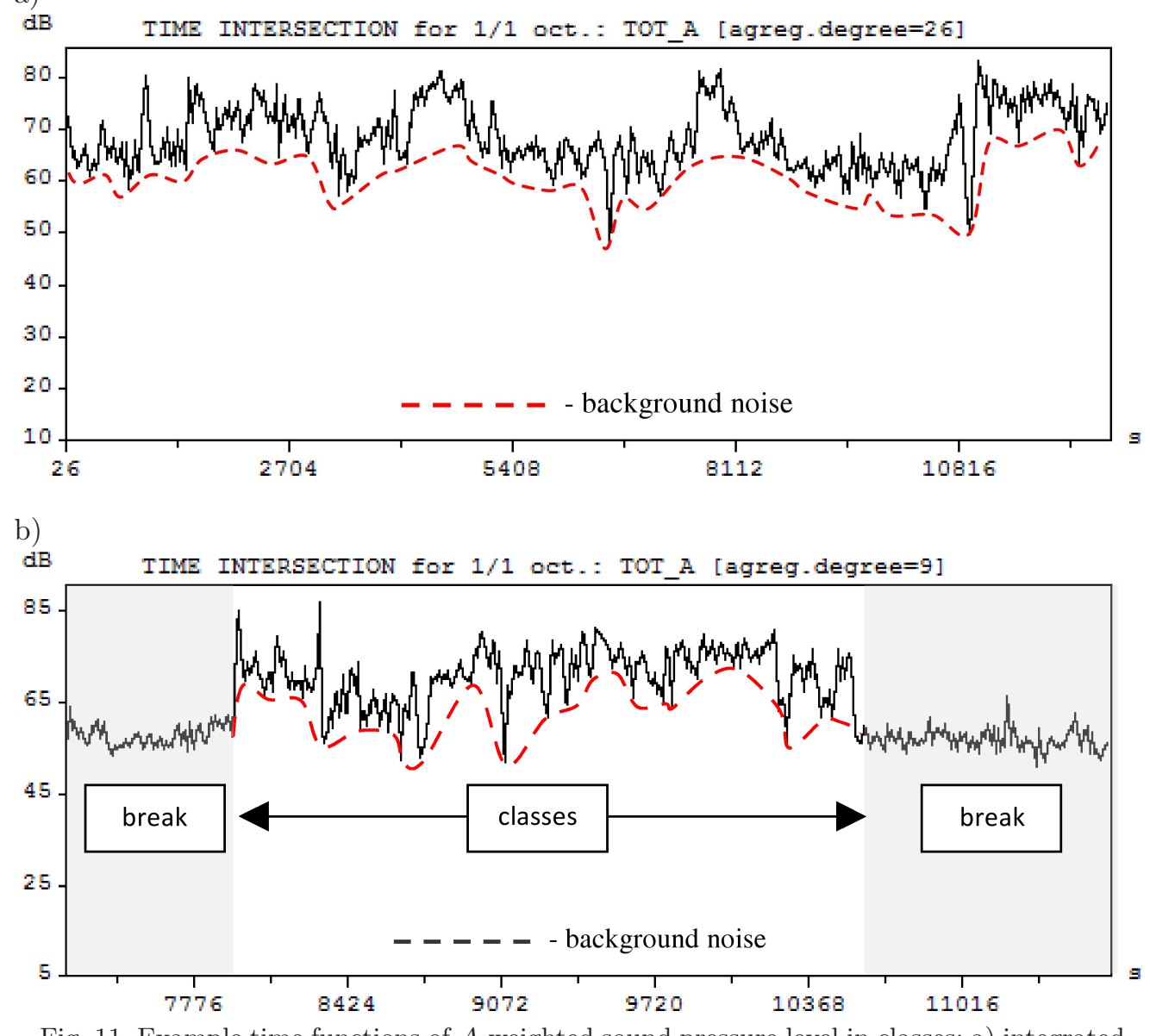

Fig. 11. Example time functions of $A$-weighted sound pressure level in classes: a) integrated education, b) history lesson.

equivalent continuous sound pressure levels measured on teachers' work posts equal 79.2-80.9 dB, and maximum $A$-weighted sound pressure levels range from 90.3 to $96.1 \mathrm{~dB}$ (peak noise levels reach $107.2-111 \mathrm{~dB}$ ).

High noise levels are also present in lunchrooms during the lunch break. $A$-weighted equivalent continuous sound pressure levels are $78.4-80.8 \mathrm{~dB}$, maximum levels - 84.5-88.6 dB (peak levels 99-108.4 dB). Teachers in younger classes supervising children during lunch are especially exposed to such noise levels.

Common rooms are considered as loud as lunchrooms. $A$-weighted equivalent continuous sound pressure levels are $74.7-80.3 \mathrm{~dB}$, and maximum $A$-weighted sound pressure levels oscillate between 81.4 and $110.5 \mathrm{~dB}(C$-weighted peak noise levels are 99-114.2 dB, respectively).

Libraries and teachers' rooms are considered relatively quiet during classes. $A$-weighted equivalent continuous sound pressure levels measured in two libraries 
(in schools SP1 and SP3) were $47.8 \mathrm{~dB}$ and $49.5 \mathrm{~dB}$, respectively, whereas the $A$-weighted equivalent continuous sound pressure level in the SP2 school library is over $10 \mathrm{~dB}$ higher at $60 \mathrm{~dB}$.

In all measured school libraries, noise level during breaks is significantly higher; $A$-weighted equivalent continuous sound pressure levels are in the 58.4$62.6 \mathrm{~dB}$ range.

In teachers' rooms, the $A$-weighted equivalent continuous sound pressure levels during breaks range from 61.9 to $73.9 \mathrm{~dB}$. During classes, they are adequately lower at $45.8 \mathrm{~dB}$ and $49.7 \mathrm{~dB}$ in schools SP1 and SP3 and $58 \mathrm{~dB}$ in school SP2.

High noise levels are also present in classrooms during classes. $A$-weighted equivalent continuous sound pressure levels are in the 66.5-74.3 $\mathrm{dB}$ range, and maximum $A$-weighted sound pressure levels range from 80 to $97.4 \mathrm{~dB}(C$-weighted peak noise levels range from $89.8 \mathrm{~dB}$ to $114.2 \mathrm{~dB}$ ). In schools SP1 and SP2, $A$-weighted equivalent continuous sound pressure levels are slightly higher in integrated teaching classes (classes I-III) than in older classes.

$A$-weighted equivalent continuous sound pressure levels in classes are defined as equivalent teacher's speech level and background noises, i.e. noise transmitted into classrooms from all external sources. As can be seen in the noise time courses presented in Fig. 11, background $A$-weighted sound pressure levels are in the 55$65 \mathrm{~dB}$ range. Teacher's voice $A$-weighted sound pressure levels range from 65 to $75 \mathrm{~dB}$. This leads to the conclusion that teachers use raised voice (according to EN ISO 9921, teacher's voice effort is considered normal if the voice $A$-weighted sound pressure level, measured from a distance of 1 metre from the mouth of the speaker, equals $60 \mathrm{~dB}$; voice is considered raised if that level has a value of $66 \mathrm{~dB}$ ).

Noise measurements outside of school buildings have shown exterior $A$-weighted equivalent continuous sound pressure levels of $54.3 \mathrm{~dB}$ (SP2), $55.7 \mathrm{~dB}$ (SP1) and $56.3 \mathrm{~dB}$ (SP3). Therefore, in two schools (SP1 and SP2), the maximum admissible environment $A$-weighted equivalent continuous sound pressure level for built-up areas with permanent or temporary presence of children and youth (55 dB), as defined by the Ordinance of the Minister of Environment (2007) is exceeded. Exterior noise can also affect background noise in classes with windows opened.

The results of noise assessment in teachers' work posts presented above have confirmed the results of research conducted earlier by Polish institutions (AUGUSTYŃSKA, RAdOSZ, 2009a; BRONDER, 2003; KosZARnY, 1990; 1992) suggesting the prevalence of high noise levels in Polish schools. They have also shown that noise is the primary annoying environment factor in teachers' work. Exceed levels from 3 to $25 \mathrm{~dB}$ over the admissible $A$-weighted equivalent continuous sound pressure level value in work posts $(55 \mathrm{~dB}$ - noise annoyance criterion according to PN-N-01307:1994) are present in most teachers' work posts (Fig. 8). The admissible background noise levels in classrooms (40 dB) (PN-B-02151-02:1987), i.e. the noise transmitted into the classrooms and school laboratories from all noise sources, are usually exceeded by $15-25 \mathrm{~dB}$. 
In this situation, there is a risk that unfavourable effects of noise as an annoying factor might arise, including subjective feelings and health ailments of teachers.

Analysis of correlation between subjective evaluation of noise annoyance and noise measurements has shown statistically significant connections between subjective evaluation of noise annoyance and the actual noise level in corridors and in the teacher's room (Table 5). However, no statistically significant correlation between the subjective evaluation of noise annoyance and the actual noise levels in classrooms during classes. The results show that subjective annoyance of noise depends on the source of the noise and the level of control over its emission. During classes, even if the admissible noise level is exceeded, it is not perceived as annoying. In didactic activities, a large part of the noise is caused by the voice of the teacher. If the noise originates from pupils, it can also be controlled by the teacher. When teachers are working in the corridor or resting in the teachers' room, their ability to control the noise level is lesser, therefore the noise is perceived as more annoying.

Table 5. Correlation between subjective noise annoyance evaluation and objective noise level measurements in researched schools.

\begin{tabular}{|c|c|c|c|c|}
\hline \multicolumn{2}{|c|}{} & \multicolumn{3}{|c|}{$\begin{array}{c}\text { Equivalent } A \text {-weighted } \\
\text { sounds pressure level, } L_{\text {Aeq, Te, },[\mathrm{dB}]}\end{array}$} \\
\cline { 3 - 5 } & in classrooms & in corridors & in teachers' room \\
\hline \multirow{2}{|c|}{$\begin{array}{c}\text { Subjective noise } \\
\text { annoyance evaluation }\end{array}$} & Pearson correlation & 0.05 & $0.18^{*}$ & $0.18^{*}$ \\
\cline { 2 - 5 } & $p$ & 0.516 & 0.014 & 0.015 \\
\hline
\end{tabular}

* significance level $p<0.05$

School noise can also contribute to development of teachers' occupational diseases (permanent hearing loss and chronic voice disorders) ("Ordinance of Council of Ministers...", 2009). The determined noise exposure levels normalized to the nominal working week in most teachers' work posts range from 66 to $78 \mathrm{~dB}$ (see Table 6$)$ and do not exceed the the admissible value $(85 \mathrm{~dB})$, which is the criterion of noise harmfulness (Maximum Admissible Intensities values - established for all workers with regard to proved harmful effect of noise on hearing). Therefore, the risk of permanent hearing loss should be assessed as low. The low number of such cases in the Education section, i.e. in education-related institutions proves this point - 47 cases total in years 1999-2008 ("Occupational diseases...", 19982008). However, with the high noise levels of over $80 \mathrm{~dB}$ in school corridors during breaks and in school sports halls, PE teachers and persons with sensitive hearing are still in risk. This applies to both teachers and pupils.

As stated earlier, high background noise levels in classrooms force the teachers to raise voice. This results in a higher vocal effort (the so-called Lombard effect) and can be one of the causes of an occupational disease - chronic voice disorders 
Table 6. Noise exposure levels normalized to the nominal working week.

\begin{tabular}{|c|c|c|c|}
\hline No. & Work post type & $\begin{array}{c}\text { Noise exposure level } \\
L_{E X, w}[\mathrm{~dB}]\end{array}$ & MAI value multiplicity \\
\hline 1. & $\begin{array}{c}\text { Work posts of integrated education } \\
\text { teachers and teachers of other subject }\end{array}$ & $66.1 \div 75$ & $0.05 \div 0.17$ \\
\hline 2. & $\begin{array}{c}\text { Work posts of teachers working } \\
\text { in common rooms }\end{array}$ & $71.6 \div 77.2$ & $0.05 \div 0.17$ \\
\hline 3. & Work posts of PE teachers & $72.3 \div 78.2$ & $0.05 \div 0.22$ \\
\hline
\end{tabular}

due to excessive vocal effort lasting for at least 15 years. In 2008 alone, 785 cases of this disease have been registered in the Education section.

The research of voice disorders causes, conducted by the Institute of Occupational Medicine and Environmental Health in Sosnowiec (BRONDER, 2003) has shown that the most commonly reported voice mechanism ailments are: dryness of the pharyngeal and laryngeal mucosa, lowering of voice pitch, throat irritation and hoarseness. All teachers with the aforementioned ailments exhibit objective deviation, such as abnormalities of the pharyngeal and laryngeal mucosa, abnormal phonatory closure of the glottis and presence of interlaryngeal hyperfunction signs. Dominating development factors of teachers' speech disorders are: long job tenure, large weekly work load, subject taught (physical education, primary education), duration of raised voice use and stress at work. Unfavourable acoustic conditions in didactic rooms, such as high background noise level and long reverberation period, are also considered risk factors.

\subsection{Research results of acoustic properties of school rooms}

Research results of acoustic properties (reverberation time and speech transmission index - STI) of school rooms in 3 examined schools have been presented in Figs. 12 and 13.

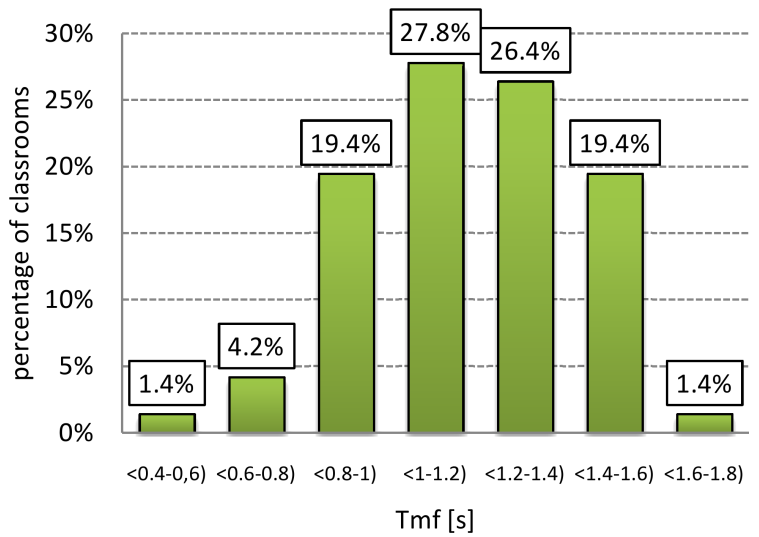

Fig. 12. Distribution of reverberation time values $T_{m f}$ in classrooms $(n=72)$. 


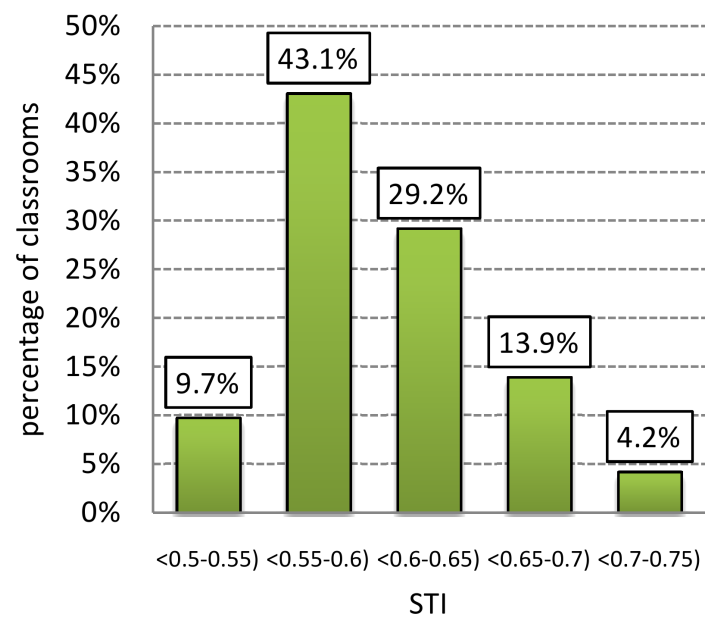

Fig. 13. Distribution of speech transmission index (STI) in classrooms $(n=72)$.

Measurements were taken in unoccupied room with the impulse method and using a pseudo-random MLS signal (EN ISO 3382-2:2008). Both the abovementioned values were measured in at least three spots of a room. The measurements results were arithmetically averaged.

Research has shown that the average reverberation time $\left(T_{m f}\right.$ - arithmetic average of reverberation times for the frequencies of 500, 1000 and $2000 \mathrm{~Hz}$ ) calculated in 72 classrooms is in the range of $0.8-1.7$ sec. (Fig. 12); the speech transmission index is $0.55-0.75$ (Fig. 13). The reverberation time in most classrooms $(98.6 \%)$ exceeds the recommended limit of $T_{\mathrm{opt}}=0.6 \mathrm{~s}$ (VAllet, KarabiBer, 2002; "Technical requirements...", 2009).

The speech transmission index does not meet the recommended condition STI > 0.6 (requirement for good speech clearness) (EN ISO 9921:2003; EN 6026816:2003) in $53 \%$ of classrooms.

Research results of acoustic properties of school rooms will be discussed in detail in a separate paper.

\section{Conclusions}

Analysis of the results of noise risk assessment in teachers' work posts in primary schools has allowed for formulation of the following conclusions:

1. Noise in teachers' work posts is the primary annoying factor of their working environment. Over $50 \%$ of surveyed teachers assess the noise as annoying, and almost $43 \%$ as very annoying or hardly bearable. This is confirmed by objective noise measurements, which indicate that the admissible value of $55 \mathrm{~dB}$, considered the criterion of noise annoyance in rooms intended for theoretic work, data processing and other similar activities, is exceeded. This condition is 
present in most teachers' work spaces in classrooms, teachers' rooms, common rooms and libraries. Admissible classroom background noise values (40 dB) are also exceeded; this refers to noise transmitted into classrooms and school laboratories from all noise sources. This creates the risk of unfavourable effects of noise as a annoying factor, as subjective feelings and ailments of teachers. The most common subjective feelings and ailments, reported by most surveyed teachers (over 90\%) are: increasing fatigue during the day, increase of psychological and emotional tension, feeling of nervousness and irritation, concentration difficulties, hoarseness and cough.

Research has shown statistically significant correlation between the subjective annoyance assessment and the frequency of the aforementioned subjective ailments and feelings. Correlation between the subjective assessment of noise annoyance and objective noise measurements in corridors and in the teachers' room.

2. School noise can also contribute to development of teachers' occupational diseases (permanent hearing loss and chronic voice disorders). The determined noise exposure levels normalized to the nominal working week in most teachers' work posts range from 66 to $78 \mathrm{~dB}$ (see Table 6) and do not exceed the the admissible value $(85 \mathrm{~dB})$, which is the criterion of noise harmfulness (MAI values - established for all workers with regard to proved harmful effect of noise on hearing). Therefore, the risk of permanent hearing loss should be assessed as low. The low number of such cases in the Education section, i.e. in education-related institutions proves this point - 47 cases total in years 19992008 ("Occupational diseases...", 1998-2008). However, with the high noise levels of over $80 \mathrm{~dB}$ in school corridors during breaks and in school sports halls, PE teachers and persons with sensitive hearing are still in risk. This applies to both teachers and students.

High background noise levels in classrooms force the teachers to raise voice to ensure better speech comprehension. This leads to increased vocal effort and can cause an occupational disease - chronic voice disorders due to excessive vocal effort lasting for at least 15 years. In 2008 alone, 785 cases of this disease have been registered in the Education section ("Occupational diseases...", 1998-2008).

3. Unfavourable acoustic properties of school rooms in researched schools (especially long reverberation time in most researched classrooms - ranging from 0.8 to $1.7 \mathrm{sec}$.) have an effect on the increase of general noise level in rooms. They also lower the quality of speech reception; in over $50 \%$ classrooms, the speech transmission index (STI) does not reach the value of 0.6 (which is the condition for good speech clearness). In such conditions, the teaching and learning processes are hampered.

4. Research conducted will be the basis for preparation of noise threat prevention guidelines for schools, including technical, organisational and medical prevention, which is being prepared by the Central Institute for Labour Protection. 


\section{Acknowledgments}

The Authors wish to thank Andrzej Najmiec, MSc, for performing the statistical analysis.

This paper has been prepared on the basis of the results of a research task carried out within the scope of the first stage of the National Programme "Improvement of safety and working conditions" partly supported in 2008-2010 within the scope of state services - by the Ministry of Labour and Social Policy.

\section{References}

1. Astolfi A., Pellerey F. (2008), Subjective and objective assessment of acoustical and overall environmental quality in secondary school classrooms, Journal of the Acoustical Society of America, 123, 1, 163-173.

2. Augustyńska D., Radosz J. (2009a), Noise at schools (1) - a review of researches [in Polish: Hałas w szkołach (1) - przeglad badań], Bezpieczeństwo Pracy - Nauka i Praktyka, 9, 16-19.

3. Augustýnska D. Radosz J. (2009b), Noise at schools (2) - the effect of school noise on learners and teachers and prevention, [in Polish: Hałas w szkołach (2) - wpływ hałasu szkolnego na uczniów i nauczycieli oraz jego profilaktyka], Bezpieczeństwo Pracy - Nauka i Praktyka, 10, 8-10.

4. Bradley J.S., Sato H. (2008), The intelligibility of speech in elementary school classrooms, Journal of Acoustical Society of America, 123, 4, 2078-2086.

5. Bronder A. (2003), Study of phenomenon of voice disorders in the population of teachers and the prevention rules. Doctor's thesis, [in Polish: Badanie przyczyn zaburzen narzadu głosu nauczycieli i opracowanie zasad profilaktyki. Rozprawa doktorska], Institute of Occupational Medicine and Environmental Health in Sosnowiec, Sosnowiec, Poland.

6. EN 60268-16:2003, Sound system equipment. Part 16: Objective rating of speech intelligibility by speech transmission index, European Committee for Standardization.

7. EN ISO 3382-2:2008, Acoustics. Measurements of room acoustics parameters. Part 2: Reverberation time in ordinary rooms, European Committee for Standardization.

8. EN ISO 9921:2003, Ergonomics - Assessment of Speech Communications, European Committee for Standardization.

9. Hanke W. et al. (2009), CEHAP - Children Environment and Health Action Plan, [in Polish: Plan dotyczacy środowiska $i$ zdrowia dzieci], Ministry of Health, Ministry of the Environment, WHO Polska, IMP, Łódź, 2009.

10. KosZarny Z. (1992), Evaluation of school noise by teachers and assessment of its effect on health and general feeling, [in Polish: Ocena hałasu szkolnego przez nauczycieli oraz jego wptywu na stan zdrowia i samopoczucie], Rocznik PZH, 43, 2.

11. Koszarny Z., Chyla A. (2003), School rooms' acoustic characteristics, [in Polish: Wtaściwości akustyczne pomieszczeń szkolnych], Rocznik PZH, 54, 3, 311-320.

12. Koszarny Z., Goryński P. (1990), Pupils's and teachers's exposure to noise in school, [in Polish: Narażenie uczniów i nauczycieli na hałas w szkole], Rocznik PZH, 41, 5-6. 
13. Lundquist P., Holmberg K., Landstrom U. (2000), Annoyance and effects on work from environmental noise at school, Noise \& Health, 2, 8, 39-46.

14. Occupational diseases in Poland in 1999-2008 (1999-2008) [in Polish: Choroby zawodowe $w$ Polsce w latach 1999-2008], Nofer Institute of Occupational Medicine, Łódź, Poland.

15. Ordinance of the Council of Ministers of June $30^{\text {th }}$, 2009 on the occupational diseases, (2009), [in Polish: Rozporzadzenie Rady Ministrów z dnia 30 czerwca 2009 r. w sprawie chorób zawodowych], Dz. U. Nr 105, poz. 869.

16. Ordinance of the Minister of Environment of June 14th, 2007 on the admissible noise levels in the environment, (2007), [in Polish: Rozporzadzenie Ministra Środowiska z dnia 14 czerwca 2007 r. w sprawie dopuszczalnych poziomów hałasu w środowisku], Dz. U. 2007, Nr 120, poz. 826 .

17. Ordinance of the Minister of Infrastructure of April 12th, 2002 on the technical requirements to be met by buildings and their location, (2002) [in Polish: Rozporzadzenie Ministra Infrastruktury z dnia 12 kwietnia 2002 r. w sprawie warunków technicznych jakim powinny odpowiadać budynki i ich usytuowanie], Dz. U., Nr 75, poz. 690, ost. zm. 2008, Nr 201, poz. 1238.

18. Ordinance of the Minister of Labour and Social Policy of November 29th, 2002 on the maximum admissible values concentration ant intensities for agents harmful to health in the working environment, (2002), [in Polish: Rozporzadzenie Ministra Pracy i Polityki Społecznej z dnia 29 listopada 2002 r. w sprawie najwyższych dopuszczalnych stężen i natężen czynników szkodliwych dla zdrowia w środowisku pracy], Dz. U. Nr 217, poz. 1833, zm. Dz. U. 2005, nr 212, poz. 1769; Dz. U. 2007, nr 161, poz. 1142, Dz. U. 2009, Nr 105, poz. 873 .

19. OSH in the school curriculum: requirements and activities in the EU Members States. Working Environment Information (2009), European Agency for Safety and Health at Work, Luxembourg.

20. PN-B-02151-02:1987, Building acoustics. Noise protection of apartments in buildings. Permissible values of sound level, [in Polish: Akustyka budowlana. Ochrona przed hałasem pomieszczeń w budynkach. Dopuszczalne wartości poziomu dźwięku w pomieszczeniach], Polish Committee for Standardization.

21. PN-B-02151-03:1999, Building acoustics. Noise protection in buildings - sound insulation in buildings and of building elements. Requirements, [in Polish: Akustyka budowlana. Ochrona przed hałasem $w$ budynkach - izolacyjność akustyczna przegród w budynkach oraz izolacyjność akustyczna elementów budowlanych. Wymagania], Polish Committee for Standardization.

22. PN-ISO 9612:2004, Acoustics. Determination of occupational noise exposure - requirements, [in Polish: Akustyka. Wytyczne do pomiarów i oceny ekspozycji na hałas w środowisku pracy], Polish Committee for Standardization.

23. PN-N-01307:1994, Noise. Permissible values of noise in the workplace. Requirement relating to measurements, [in Polish: Hałas. Dopuszczalne wartości hałasu w środowisku pracy. Wymagania dotyczace wykonywania pomiarów], Polish Committee for Standardization.

24. Sato H., Bradley J.S. (2008), Evaluation of acoustical conditions for speech communication in working elementary school classrooms, Journal of the Acoustical Society of America, 123, 4, 2064-2077. 
25. Shield B., Dockrell J.E. (2004), External and internal noise surveys of London primary schools, Journal of the Acoustical Society of America, 115, 2, 730-738.

26. Smith E., Lemke J., Taylor M., Kirchner H.L., Hoffman H. (1998), Frequency of Voice Problems Among Teachers and Other Occupations, Journal of Voice, 12, 4, 480-488.

27. Technical requirements to be met by buildings and their location (2009), [in Polish: Warunki techniczne jakim powinny odpowiadać budynki i ich usytuowanie - Tekst ujednolicony po nowelizacji z komentarzem], Building Research Institute, Warszawa, Poland.

28. Vallet M., Karabiber Z. (2002), Some European policies regarding acoustical comfort in educational buildings, Noise Control Engineering Journal, 50, 2, 58-62.

29. Vilkman E. (2004), Occupational Safety and Health Aspects of Voice and Speech Professions, Folia Phoniatrica et Logopaedica, 56, 4, 220-253.

30. Walinder R., Gunnarsson K., Runeson R., Smedje G. (2007), Physiological and psychological stress reactions in relation to classroom noise, Scandinavian Journal of Work, Environment \& Health, 33, 4, 260-266. 